\title{
Polycystic Kidney Disease Protein 1-Like 2
}

National Cancer Institute

\section{Source}

National Cancer Institute. Polycystic Kidney Disease Protein 1-Like 2. NCI Thesaurus. Code C150297.

Polycystic kidney disease protein 1-like 2 (2459 aa, $273 \mathrm{kDa}$ ) is encoded by the human PKD1L2 gene. This protein may play a role in calcium transport and receptor signaling. 